\title{
Evaluation of gender differences in physiology: an introduction.
}

Citation for published version (APA):

Tarnopolsky, M. A., \& Saris, W. H. M. (2001). Evaluation of gender differences in physiology: an introduction. Current Opinion in Clinical Nutrition and Metabolic Care, 4, 489-492. https://doi.org/10.1097/00075197-200111000-00004

Document status and date:

Published: 01/01/2001

DOI:

10.1097/00075197-200111000-00004

Document Version:

Publisher's PDF, also known as Version of record

\section{Please check the document version of this publication:}

- A submitted manuscript is the version of the article upon submission and before peer-review. There can be important differences between the submitted version and the official published version of record.

People interested in the research are advised to contact the author for the final version of the publication, or visit the DOI to the publisher's website.

- The final author version and the galley proof are versions of the publication after peer review.

- The final published version features the final layout of the paper including the volume, issue and page numbers.

Link to publication

\footnotetext{
General rights rights.

- You may freely distribute the URL identifying the publication in the public portal. please follow below link for the End User Agreement:

www.umlib.nl/taverne-license

Take down policy

If you believe that this document breaches copyright please contact us at:

repository@maastrichtuniversity.nl

providing details and we will investigate your claim.
}

Copyright and moral rights for the publications made accessible in the public portal are retained by the authors and/or other copyright owners and it is a condition of accessing publications that users recognise and abide by the legal requirements associated with these

- Users may download and print one copy of any publication from the public portal for the purpose of private study or research.

- You may not further distribute the material or use it for any profit-making activity or commercial gain

If the publication is distributed under the terms of Article $25 \mathrm{fa}$ of the Dutch Copyright Act, indicated by the "Taverne" license above, 


\section{Evaluation of gender differences in physiology: an introduction Mark A. Tarnopolsky ${ }^{a}$ and Wim H.M. Saris ${ }^{b}$}

\author{
aDepartment of Medicine (Neurology and Neurological Rehabilitation) and \\ Kinesiology, McMaster University Medical Center, Hamilton, Ontario, Canada and \\ ${ }^{b}$ Nutrition and Toxicology Research Institute Maastricht (NUTRIM), Medical and \\ Health Science School, University of Maastricht, The Netherlands \\ Correspondence to Dr M.A. Tarnopolsky, Department of Medicine, McMaster \\ University Medical Center, Room 4U4 Neurology, 1200 Main St. W., Hamilton, \\ Ontario, Canada L8N $3 Z 5$ \\ Tel: +1905 5212100 (75226); fax: +1905 521 2656; \\ e-mail: tarnopol@mcmaster.ca \\ Current Opinion in Clinical Nutrition and Metabolic Care 2001, 4:489-492 \\ (C) 2001 Lippincott Williams \& Wilkins \\ 1363-1950
}

The overall theme of the current section is an evaluation of gender differences in physiology. Cognizant of the broad scope of the topic, we will limit this to muscle physiology and whole body energy and macronutrient metabolism. Given the massive increase in strain placed upon a physiological system in response to physical exercise, the articles will focus mostly on exercise as a major theme to illustrate gender differences in physiology.

An understanding of the physiology of exercise has broad implications for many pathological states. For example, exercise is an established therapeutic and evaluation modality in coronary artery disease, while the metabolic changes with exercise are somewhat analogous to short-term starvation, being a common state in institutionalized patients.

For years there has been evidence of a gender bias in bio-medical research [1,2]. This became apparent upon review of the large clinical studies that evaluated cardiovascular disease medications in the 1960s and 1970s [3]. As a result of this gender bias, agencies such as the National Institute of Health in the United States mandated that equal numbers of males and females be included in bio-medical research. As a result of increased awareness, this bias may be less apparent, however there are still several examples of its continued presence [1,2].

In the area of exercise physiology, the area was largely ignored, perhaps due to early work suggesting that there were no gender differences in metabolism or muscle morphology $[4,5]$. At a practical level, most of the current recommendations for exercise training and nutrition have been derived from studies that contained primarily or exclusively male participants [6-9]. One of the most graphic examples of gender bias comes form the fact that women were not allowed to compete in the Olympic marathon until 1984. While the reasons for an inherent gender bias in the physiology literature are likely multifactorial, the need to control for menstrual cycle and the perception that females may be less willing to undergo invasive procedures such as muscle biopsies have been cited anecdotally by some researchers. In reality, it has been our experience in recent years that females are in fact more willing to volunteer for studies involving muscle biopsies and other minor procedures.

This gender bias is even more poignant given recent evidence that has shown that females may in fact be better suited to ultra-endurance sports compared with males [10]. A 'field' study matched males and females for performance times at the $56 \mathrm{~km}$ distance and found that the females outperformed the males at the $90 \mathrm{~km}$ distance [10]. Regression analysis has shown that males outperform females at distances up to $\sim 42 \mathrm{~km}$, with an increasing performance advantage for females above an intercept of $66 \mathrm{~km} \mathrm{[10].} \mathrm{Another} \mathrm{group} \mathrm{reported} \mathrm{that}$ equally trained males and females performed similarly at $42 \mathrm{~km}$, yet the females outperformed the males at the $90 \mathrm{~km}$ distance [11].

The mechanism behind the aforementioned performance observations may relate to metabolic substrate selection, differences in muscle oxidative stress or damage, or even differences in thermo-regulation. In carefully controlled studies examining metabolic substrate selection during exercise, it has been consistently demonstrated that females utilize proportionately more lipid and less carbohydrate and protein than males (see Table 1 and the review by Tipton (pp. 493-498)). It is interesting that the gender dimorphism in substrate selection only becomes apparent under physiological stress for there is good evidence from studies using large numbers of participants that under resting conditions, the aforementioned gender differences are not apparent [12]. Individual articles evaluate potential gender differences and the role of sex hormones in macronutrient selection (fat, carbohydrate and protein). The paper by Blaak (pp. 499-502) focuses on the differences in fat utilization. The review by Tipton also considers the issue regarding gender differences in muscle mass and the response of muscle protein turnover to resistance exercise. The potential for gender differences in muscle strength and neuronal input during the aging process and the possible role of sex hormones are both evaluated by 
Table 1. Summary of studies where whole body substrate metabolism was reported in males and females

\begin{tabular}{|c|c|c|c|}
\hline Reference & Subjects & Exercise & RER (mean) \\
\hline Costill et al. (1979) [4] & $\begin{array}{l}12 \mathrm{~F}, \mathrm{~T} \\
12 \mathrm{M}, \mathrm{T}\end{array}$ & 60 min run @ $70 \% \mathrm{VO}_{2 \max }$ & $\begin{array}{l}F=0.83 \\
M=0.84\end{array}$ \\
\hline Froberg and Pedersen (1984) [34] & $\begin{array}{l}7 \mathrm{~F}, \mathrm{~T} \\
7 \mathrm{M}, \mathrm{T}\end{array}$ & to exhaustion @ $80+90 \% \mathrm{VO}_{2 \max }$ & $\begin{aligned} F & =0.93 \\
M & =0.97\end{aligned}$ \\
\hline Blatchford et al. (1985) [35] & $\begin{array}{l}6 \mathrm{~F}, \mathrm{~T} \\
6 \mathrm{M}, \mathrm{T}\end{array}$ & 90 min walk @ $35 \% \mathrm{VO}_{2 \max }$ & $\begin{aligned} F & =0.81 \\
M & =0.85\end{aligned}$ \\
\hline Tarnopolsky et al. (1990) [22] & $\begin{array}{l}6 \mathrm{~F}, \mathrm{~T} \\
6 \mathrm{M}, \mathrm{T}\end{array}$ & $15.5 \mathrm{~km}$ run @ 65\% $\mathrm{VO}_{2 \max }$ & $\begin{aligned} F & =0.876 \\
M & =0.940\end{aligned}$ \\
\hline Phillips et al. (1993) [21] & $\begin{array}{l}6 \mathrm{~F}, \mathrm{~T} \\
6 \mathrm{M}, \mathrm{T}\end{array}$ & 90 min cycle @ $65 \% \mathrm{VO}_{2 \max }$ & $\begin{array}{l}F=0.820 \\
M=0.853\end{array}$ \\
\hline Tarnopolsky et al. (1995) [23] & $\begin{array}{l}8 \mathrm{~F}, \mathrm{~T} \\
7 \mathrm{M}, \mathrm{T}\end{array}$ & 60 min cycle @ $75 \% \mathrm{VO}_{2 \max }$ & $\begin{aligned} F & =0.892 \\
M & =0.923\end{aligned}$ \\
\hline Tarnopolsky et al. (1997) [20] & $\begin{array}{l}8 \mathrm{~F}, \mathrm{~T} \\
8 \mathrm{M}, \mathrm{T}\end{array}$ & 90 min cycle @ $65 \% \mathrm{VO}_{2 \max }$ & $\begin{array}{l}\mathrm{F}=0.893 \\
\mathrm{M}=0.918\end{array}$ \\
\hline Horton et al. (1998) [32] & $\begin{array}{l}13 \mathrm{~F}, \mathrm{~T}+\mathrm{U} \\
14 \mathrm{M}, \mathrm{T}+\mathrm{U}\end{array}$ & 120 min cycle @ 45\% VO $\mathrm{V}_{2 \max }$ & $\begin{aligned} \mathrm{F} & =0.84 \\
\mathrm{M} & =0.86\end{aligned}$ \\
\hline Freidlander et al. (1998) [31] & $\begin{array}{l}17 \mathrm{~F}, \mathrm{UT} \rightarrow \mathrm{T} \\
19 \mathrm{M}, \mathrm{UT} \rightarrow \mathrm{T}\end{array}$ & 60 min cycle @ 45 and $65 \% \mathrm{VO}_{2 \max }$ & $\begin{array}{l}\mathrm{F}=0.885 \\
\mathrm{M}=0.932\end{array}$ \\
\hline Romijn et al. (2000) [36] & $\begin{array}{l}8 \mathrm{~F}, \mathrm{~T} \\
5 \mathrm{M}, \mathrm{T}\end{array}$ & 20-30 min cycle @ 65\% VO $\mathrm{V}_{2 \max }$ & $\begin{aligned} F & =0.81 \\
M & =0.81\end{aligned}$ \\
\hline McKenzie et al. (2000) [30] & $\begin{array}{l}6 \mathrm{~F}, \mathrm{UT} \rightarrow \mathrm{T} \\
6 \mathrm{M}, \mathrm{UT} \rightarrow \mathrm{T}\end{array}$ & 90 min cycle @ $65 \% \mathrm{VO}_{2 \max }$ & $\begin{array}{l}F=0.889 \\
M=0.914\end{array}$ \\
\hline Davis et al. (2000) [33] & $\begin{array}{l}8 \mathrm{~F}, \mathrm{UT} \\
8 \mathrm{M}, \mathrm{UT}\end{array}$ & 90 min cycle @ $50 \% \mathrm{VO}_{2 \max }$ & $\begin{array}{l}F=0.92 \\
M=0.92\end{array}$ \\
\hline Goedecke et al. (2000) [37] & $16 \mathrm{~F}, \mathrm{~T}$ & $\begin{array}{l}10 \min \text { cycle @ } 25,50 \text { and } 75 \% \\
\mathrm{VO}_{2 \max }\end{array}$ & $\mathrm{F}=0.90$ \\
\hline Rennie et al. (2000) [38] & $\begin{array}{c}45 \mathrm{M}, \mathrm{T} \\
6 \mathrm{~F}, \mathrm{UT} \rightarrow \mathrm{T} \\
5, \mathrm{M} \text { UT } \rightarrow \mathrm{T}\end{array}$ & 90 min cycle @ 60\% VO $\mathrm{VO}_{2 \max }$ & $\begin{aligned} M & =0.92 \\
F & =0.893 \\
M & =0.945\end{aligned}$ \\
\hline Carter et al. (2001) [19] & $\begin{array}{l}8 \mathrm{~F}, \mathrm{UT} \rightarrow \mathrm{T} \\
8 \mathrm{M}, \mathrm{UT} \rightarrow \mathrm{T}\end{array}$ & 90 min cycle @ $60 \% \mathrm{VO}_{2 \max }$ & $\begin{array}{l}\mathrm{F}=0.847 \\
\mathrm{M}=0.900\end{array}$ \\
\hline Mean & $\begin{array}{l}135 \mathrm{~F} \\
162 \mathrm{M}\end{array}$ & & $\begin{array}{l}\mathrm{F}=0.869(0.04) \\
\mathrm{M}=0.900(0.04)^{\star}\end{array}$ \\
\hline
\end{tabular}

Values are mean (SD). For longitudinal training studies, the pre/post rides are all collapsed across time for each gender. A, active; $F$, females; $\mathrm{M}$, males; $\mathrm{T}$, trained; $\mathrm{U}$, untrained; $\mathrm{U} \rightarrow \mathrm{T}$, longitudinal training study; $\mathrm{T}+\mathrm{U}$, trained and untrained in same study. $\mathrm{RER}=$ respiratory exchange rate. * Significant gender difference $(P<0.05)$.

Doherty (pp. 503-508). Although much of the focus of this section is on human studies, there is much that has been found in animal studies [13-17]. As a result, two of the reviews will focus primarily on animal models of muscle damage/oxidative stress (Tiidus, pp. 509-513) and substrate selection during exercise (Campbell and Febbraio, pp. 515-520).

From a practical perspective, there are many issues that must be considered when conducting gender comparative studies. First, the average female has a higher percentage of body fat $(\sim 5-10 \%)$ and lower muscle mass compared with the average male [18-23]. Therefore, it is important to express indicators of fitness (i.e. maximal aerobic capacity, $\mathrm{VO}_{2 \max }$ ) relative to fat-free mass, as a between-gender comparison based upon absolute $\mathrm{VO}_{2 \max }$ would lead to the selection of females who are heavier than the males. Sparling (pp. 000-000) has also suggested gender matching consideration and assessment of habitual activity in the year before testing [24]. Cureton presents a convincing argument for comparing the genders based upon training history for trained individuals, and $\mathrm{VO}_{2 \max }$ expressed relative to lean mass in untrained individuals [25]. In between- gender comparison studies, it is best to match the groups based upon assessment of both training history and $\mathrm{VO}_{2 \max }$ expressed relative to lean body mass $\left(\mathrm{ml} \mathrm{O}_{2} /\right.$ $\mathrm{kg} \mathrm{LBM} / \mathrm{min}$ ). This matching approach takes into account both the genetic $\left(\mathrm{VO}_{2 \max }\right.$ potential) and environmental (training state) factors contributing to $\mathrm{VO}_{2 \max }$, and expresses them relative to the mass of metabolically active tissues.

An additional issue in studies using athletes is the importance of testing at an exercise intensity at/or below $75 \%$ of $\mathrm{VO}_{2 \max }(<65 \%$ for non-athletes) such that potential differences in lactate threshold between the groups do not influence the results [26]. Using the above-mentioned selection criteria, we have found that the lactate threshold is about $80 \%$ for well-trained males and females (males $=79.4 \pm 1.4 \%$; females $=80.1 \pm 2.7 \%$ ) [21]. To overcome the issue of inter-group differences in fitness, a longitudinal approach can be taken to studies where untrained people are placed on a set exercise program to ensure equality of training.

Another critical factor to consider in gender comparative studies is the phase of the menstrual cycle and 
whether or not the females are having regular menses (eumenorrhea) versus amenorrhea or oligoamenorrhea. During the follicular phase of the menstrual cycle (approximately the first 14 days after the onset of menses) the estradiol concentration starts at levels comparable to males and then increases until ovulation (which marks the onset of the luteal phase). During the luteal phase of the menstrual cycle the concentrations of both estrogen and progesterone are markedly elevated until a rapid drop at the onset of menses to start another cycle ( $\sim 28$ days in total).

The menstrual cycle has a significant effect on a number of physiological variables including thermogenesis and metabolism. The onset of the luteal phase is marked by an increase in basal body temperature of about $0.5^{\circ} \mathrm{C}$ and this is used as a non-invasive method to determine luteal phase onset. During the luteal phase of the menstrual cycle there is a slightly higher muscle glycogen concentration [27] and plasma glucose kinetics are also altered [28]. Protein oxidation during exercise is also higher during the luteal phase of the menstrual cycle [29]. These are just a few examples of the importance to control for menstrual cycle in any gender comparative studies.

When menstrual cycle, diet and training are considered in the matching criteria, there appears to be a higher lipid oxidation and lower carbohydrate and amino acid oxidation in females compared with males during endurance exercise [19,21-23,29-33]. When one includes all of the reports comparing men and women during endurance exercise (including those that reported no gender differences) the 'meta-analysis' still shows that females oxidize more lipid and less carbohydrate and protein compared with males during endurance exercise (Tables 1 and 2).

In spite of the increased awareness of gender differences in physiology, this area is far from being resolved. The focus of this issue on gender differences in physiology is meant to provide an awareness of the major issues in the field such that future studies further explore these differences and ultimately provide gender specific recommendations based upon the results of careful research.

Table 2. Summary of substrate utilization in several studies (see Table 1) directly comparing males and females

\begin{tabular}{lcccc}
\hline Subjects & RER & CHO (\%) & FAT (\%) & PRO (\%) \\
\hline$n=135 \mathrm{~F}$ & $0.869(0.04)$ & $56(10)$ & $41(9)$ & $2(2)$ \\
$n=162 \mathrm{M}$ & $0.900(0.04)^{\star}$ & $66(9)^{\star}$ & $28(8)^{\star}$ & $6(3)^{\star}$ \\
\hline
\end{tabular}

Values are mean $(\mathrm{SD}) .{ }^{*}$ Gender difference $(P<0.05)$. RER $=$ respiratory exchange rate; $\mathrm{CHO}=$ carbohydrate; $\mathrm{PRO}=$ protein.

\section{References}

1 Chapman KR, Tashkin DP, Pye DJ. Gender bias in the diagnosis of COPD. Chest 2001; 119:1691-1695.

2 Bandyopadhyay S, Bayer AJ, O'Mahony MS. Age and gender bias in statin trials. QJM 2001; 94:127-132.

3 Meinert CL, Gilpin AK. Estimation of gender bias in clinical trials. Stat Med 2001; 20:1153-1164.

4 Costill DL, Fink WJ, Getchell LH, et al. Lipid metabolism in skeletal muscle of endurance-trained males and females. J Appl Physiol 1979; 47:787-791.

5 Costill DL, Daniels J, Evans W, et al. Skeletal muscle enzymes and fiber composition in male and female track athletes. J Appl Physiol 1976; 40:149154.

6 Bergstrom J, Hermansen L, Hultmane E, Saltin B. Diet, muscle glycogen and physical performance. Acta Physiol Scand 1967; 71:140-150.

7 Hultman E, Bergstrom J. Muscle glycogen synthesis in relation to diet studied in normal subjects. Acta Med Scand 1967; 182:109-117.

8 Sherman WM, Costill DL, Fink WJ, Miller JM. Effect of exercise-diet manipulation on muscle glycogen and its subsequent utilization during performance. Int J Sports Med 1981; 2:114-118.

9 Karlsson J, Saltin B. Diet, muscle glycogen, and endurance performance. J Appl Physiol 1971; 31:203-206.

10 Bam J, Noakes TD, Juritz J, Dennis SC. Could women outrun men in ultramarathon races? Med Sci Sports Exerc 1997; 29:244-247.

11 Speechly DP, Taylor SR, Rogers GG. Differences in ultra-endurance exercise in performance-matched male and female runners. Med Sci Sports Exerc 1996; 28:359-365.

12 Nagy TR, Goran MI, Weinsier RL, et al. Determinants of basal fat oxidation in healthy Caucasians. J Appl Physiol 1996; 80:1743-1748.

13 Ellis GS, Lanza-Jacoby S, Gow A, Kendrick ZV. Effects of estradiol on lipoprotein lipase activity and lipid availability in exercised male rats. J Appl Physiol 1994; 77:209-215.

14 Rooney TP, Kendrick ZV, Carlson J, et al. Effect of estradiol on the temporal pattern of exercise-induced tissue glycogen depletion in male rats. J Appl Physiol 1993; 75:1502-1506.

15 Kendrick ZV, Ellis GS. Effect of estradiol on tissue glycogen metabolism and lipid availability in exercised male rats. J Appl Physiol 1991; 71:1694-1699.

16 Cortright RN, Koves TR. Sex differences in substrate metabolism and energy homeostasis. Can J Appl Physiol 2000; 25:288-311.

17 Cortright RN, Collins HL, Chandler MP, et al. Diabetes reduces growth and body composition more in male than in female rats. Physiol Behav 1996; 60:1233-1238.

18 Tarnopolsky MA, Zawada C, Richmond LB, et al. Gender differences in carbohydrate loading are related to energy intake. J Appl Physiol 2001; 91:225-230.

19 Carter SL, Renbie C, Tarnopolsky MA. Substrate utilization during endurance exercise in men and women after endurance training. Am J Physiol Endocrinol Metab 2001; 280:E898-E907.

20 Tarnopolsky MA, Bosman M, MacDonald JR, et al. Postexercise proteincarbohydrate and carbohydrate supplements increase muscle glycogen in men and women. J Appl Physiol 1997; 83:1877-1883.

21 Phillips SM, Atkinson SA, Tarnopolsky MA, et al. Gender differences in leucine kinetics and nitrogen balance in endurance athletes. J Appl Physiol 1993; 75:2134-2141.

22 Tarnopolsky LJ, MacDougall JD, Atkinson SA, et al. Gender differences in substrate for endurance exercise. J Appl Physiol 1990; 68:302-308.

23 Tarnopolsky MA, Atkinson SA, Phillips SM, MacDougall JD. Carbohydrate loading and metabolism during exercise in men and women. J Appl Physiol 1995; 78:1360-1368.

24 Sparling PB. A meta-analysis of studies comparing maximal oxygen uptake in men and women. Res Q Exerc Sport 1980; 51:542-552.

25 Cureton KJ, Sparling PB. Distance running performance and metabolic responses to running in men and women with excess weight experimentally equated. Med Sci Sports Exerc 1980; 12:288-294.

26 Tate CA, Holtz RW. Gender and fat metabolism during exercise: a review. Can J Appl Physiol 1998; 23:570-582.

27 Nicklas BJ, Hackney AC, Sharp RL. The menstrual cycle and exercise: performance, muscle glycogen, and substrate responses. Int J Sports Med 1989; 10:264-269. 
28 Zderic TW, Coggan AR, Ruby BC. Glucose kinetics and substrate oxidation during exercise in the follicular and luteal phases. J Appl Physiol 2001; 90:447-453.

29 Lamont LS, Lemon PW, Bruot BC. Menstrual cycle and exercise effects on protein catabolism. Med Sci Sports Exerc 1987; 19:106-110.

30 McKenzie S, Phillips SM, Carter SL, et al. Endurance exercise training attenuates leucine oxidation and BCOAD activation during exercise in humans. Am J Physiol Endocrinol Metab 2000, 278:E580-E587.

31 Friedlander AL, Casazza GA, Horning MA, et al. Training-induced alterations of carbohydrate metabolism in women: women respond differently from men. J Appl Physiol 1998; 85:1175-1186.

32 Horton TJ, Pagliassotti MJ, Hobbs K, Hill JO. Fuel metabolism in men and women during and after long-duration exercise. J Appl Physiol 1998; 85:1823-1832.

33 Davis SN, Galasetti P, Wasserman DH, Tate D. Effects of gender on neuroendocrine and metabolic counterregulatory responses to exercise in normal man. J Clin Endocrinol Metab 2000; 85:224-230.
34 Froberg K, Pedersen PK. Sex differences in endurance capacity and metabolic response to prolonged, heavy exercise. Eur J Appl Physiol Occup Physiol 1984; 52:446-450.

35 Blatchford FK, Knowlton RG, Schneider DA. Plasma FFA responses to prolonged walking in untrained men and women. Eur J Appl Physiol Occup Physiol 1985; 53:343-347.

36 Romijn JA, Coyle EF, Sidossis LS, et al. Substrate metabolism during different exercise intensities in endurance-trained women. J Appl Physiol 2000; 88:1707-1714

37 Goedecke JH, St Clair Gibson A, Grobler L, et al. Determinants of the variability in respiratory exchange ratio at rest and during exercise in trained athletes. Am J Physiol Endocrinol Metab 2000; 279:E1325-E334.

38 Rennie CD, Brose AN, Carter SL, Tarnopolsky MA. Muscle enzyme changes following endurance exercise in males and females. Med Sci Sports Exerc 2000; 32:S363. 